\title{
Edukacyjne aspekty aktywności zawodowej na emeryturze w świetle dzienników Haliny Semenowicz - twórczyni i propagatorki pedagogiki Freineta $w$ Polsce
}

\begin{abstract}
Abstrakt
Ważną kwestią, która wyznacza ramy poszukiwania potencjału edukacyjnego w biografii człowieka jest połączenie procesu uczenia się z codziennym światem życia jednostki. Halina Semenowicz, pisząc dzienniki, zawarła w nich opis życia codziennego, jakie prowadziła, będąc na emeryturze. W prezentowanym tekście skupię się na obszarze aktywności zawodowej, której $\mathrm{H}$. Semenowicz nie zaniechała po przejściu na emeryturę. Kontynuowała tym samym dzieło upowszechniania w Polsce technik Celestyna Freineta. Akcentując znaczenie pracy jako ważnego obszaru, w którym następuje rozwój człowieka dorosłego, uwaga została skoncentrowana na ukazaniu roli, jaką w życiu Haliny Semenowicz pełniła praca, oraz tych formach codziennej aktywności, które wiązały się z uczeniem się diarystki przebiegającym na tle podejmowanych przez nią aktywności zawodowych.
\end{abstract}

Słowa kluczowe: emerytura, aktywność zawodowa, dzienniki Haliny Semenowicz.

\section{Educational Aspects of Working Life in Retirement in the Light of Halina Semenowicz's Diaries - Founder and Propagator of Freinet Education in Poland}

\begin{abstract}
An important aspect that sets the framework for seeking educational potential in a biography of man is the combination of the learning process with the everyday world of life of an individual. Halina Semenowicz, writing journals, included in them the description of everyday life she led being retired. In this text, I will focus on the area of professional activity which $\mathrm{H}$. Semenowicz did not abandon after retirement.
\end{abstract}

* Uniwersytet Mikołaja Kopernika w Toruniu, Wydział Nauk Pedagogicznych. 
She continued the dissemination of the Celestine Freineta techniques in Poland. While emphasizing the importance of work as a crucial area in which the development of an adult takes place, I concentrated my attention on displaying the role of work in the life of Halina Semenowicz and these forms of daily activities that were associated with learning undertaken against the backgroud of professional activity.

Keywords: retirement, professional activity, Halina Semenowicz's diaries.

\section{Wprowadzenie}

Analiza biografii jednej osoby dostarcza informacji o sposobach doświadczania i interpretowania przez nią rzeczywistości, ale także pozwala wyjść poza jej indywidualną perspektywę. Prawo do bycia indywidualnością, do realizacji życia według własnych możliwości, potrzeb i oczekiwań stwarza warunki do różnicowania się biografii. Wzrasta znaczenie indywidualnych biografii, nie tylko jako wartości osobowej, ale także społecznej i edukacyjnej. Materiały biograficzne, w tym przypadku dzienniki, mają istotne znaczenie dla andragogiki. Pozwalają rekonstruować procesy kształcenia, których celem ogólnym jest pogłębienie wiedzy o sobie i świecie, a także kształtowanie kompetencji biograficznych wyrażających się w wytyczaniu planów życiowych i zawodowych. Wykorzystywane w edukacji dorosłych materiały biograficzne (tu: dzienniki) sprzyjają rozumieniu procesu nauczania i uczenia się dorosłych, przebiegającego w określonym społeczeństwie i określonym czasie historycznym. Analiza kontekstu społecznego, w jakim funkcjonuje jednostka, odzwierciedlonego w indywidualnej biografii pozwala zrozumieć jej zachowania, dążenia, wartości.

Ważną kwestią, która wyznacza ramy poszukiwania potencjału edukacyjnego w biografii człowieka, jest połączenie procesu uczenia się z codziennym światem życia jednostki. Zainteresowanie codziennością $w$ andragogice zaowocowało badaniami różnych jej obszarów jako przestrzeni uczenia się ludzi dorosłych, ich rozwoju i konstruowania tożsamości (Słowińska 2014: 92). Halina Semenowicz, pisząc dzienniki, zawarła w nich opis życia codziennego, jakie prowadziła, będąc na emeryturze. W prezentowanym tekście skupię się na obszarze aktywności zawodowej, której H. Semenowicz nie zaniechała po przejściu na emeryturę. Kontynuowała tym samym dzieło upowszechniania w Polsce technik Celestyna Freineta.

Akcentując znaczenie pracy jako ważnego obszaru, w którym następuje rozwój człowieka dorosłego, uwaga została skoncentrowana na ukazaniu roli, jaką w życiu badanej pełniła praca, oraz tych formach codziennej aktywności, które wiązały się z uczeniem się diarystki przebiegającym na tle podejmowanych przez nią aktywności zawodowych. W podjętych badaniach szukałam odpowiedzi na następujące pytania: Jaką rolę odgrywała aktywność zawodowa w życiu Haliny Semenowicz na emeryturze? Czego Halina Semenowicz uczyła się, kontynuując pracę zawodową na 
emeryturze? W jaki sposób Halina Semenowicz pisała o pracy quasi-zawodowej w dziennikach?

Ze względu na charakter źródła, tj. dzienniki Haliny Semenowicz i zawarte tam treści oraz postawione pytania badawcze, zastosowałam idiograficzny typ wyjaśnień (Rubacha 2008: 259), który prowadzi do wytworzenia szczegółowych twierdzeń, odnoszących się tylko do badanego obszaru, w tym przypadku do osoby Haliny Semenowicz w określonym społeczno-politycznym kontekście i przez to nie mogą być uogólniane. Poszukiwania badawcze podporządkowane zostały schematowi studium przypadku, który organizuje badanie określonego zjawiska (tu: aktywności zawodowej w życiu diarystki), którego wartości (obrazy) są ulokowane w życiu osoby badanej. Przedmiotem analizy były fragmenty dzienników osobistych H. Semenowicz,

\section{Aktywność zawodowa Haliny Semenowicz w świetle dzienników}

Halina Semenowicz po ukończeniu liceum, w 1930 r., pracowała przez cztery lata jako nauczycielka w szkole powszechnej Janiny Sulerzyskiej w Poznaniu. W latach 1934-1940 uczyła w szkołach dla dzieci polskich emigrantów w Belgii. Po powrocie do kraju w 1947 r., kontynuowała pracę nauczycielki w Liceum Pedagogicznym i Szkole Ćwiczeń TPD w Poznaniu, pracowała w Prewentorium Przeciwgruźliczym Bucze Harcerskie koło Cieszyna oraz w Liceum Ogólnokształcącym TPD w Poznaniu. W latach 1952-1955 pełniła funkcję kierowniczki szkoły w Prewentorium w Świdrze. Od 1955 r. kierowała szkołą podstawową w Sanatorium im. J. Marchlewskiego w Otwocku (Kościuszko 2014: 155-156). Mimo przejścia na emeryturę w roku 1970, pozostawała aktywna zawodowo. Jej uwaga skupiła się na pracy pisarskiej. Diarystka wydała w tym okresie następujące książki: Poetycka twórczość dziecka, Nasza Księgarnia, Warszawa 1972 (pokłosie pracy doktorskiej napisanej pod kierunkiem Bogdana Suchodolskiego), Chleb i Róże. Listy o wychowaniu, Nasza Księgarnia, Warszawa 1978, Freinet $w$ Polsce, WSiP, Warszawa 1980, Nowoczesna Szkoła Francuska Technik Freineta, Nasza Księgarnia, Warszawa 1966. Opracowała trzy broszury dla czasopisma dokumentalnego dla dzieci i młodzieży „Biblioteka Pracy” (Bibliothèque de travail), wydawanego przez Stowarzyszenie Spółdzielcza Edukacja Świecka we Francji (ICEM - Pédagogie Freinet): Nicolas Copernik, Bibliothèque de travail, ICEM, Cannes 1973; Frederic Chopin. Bibliothèque de travail, ICEM, Cannes 1976; Janusz Korczak et les droits des enfants. Bibliothèque de travail, ICEM, Cannes 1981. Opublikowała 12 rozdziałów w pracach zbiorowych i 42 artykuły w czasopismach pedagogicznych polskich i francuskich, m.in.: «Bibliographie Internationale», «Revue Pedagogique», „Freinetowskich Inspiracjach”, „Studia Pedagogiczne”, „Szkoła Specjalna” czy „Wychowanie w Przedszkolu” (Kościuszko 2014: 147-159). Pisanie artykułów do czasopism pedagogicznych było podyktowane różnymi zobowiązaniami. Na przykład w odniesieniu do pisma «Revue 
Pedagogique» napisała: „przysyłają mi je od kilku lat bezpłatnie, a ja im nigdy nic nie napisałam. Kopię mego pisma przesłałam z długim listem (odpowiedź na list gwiazdkowy) do mojej kochanej przyjaciółki Paulette Quarante z Marsylii. Może się ten tekst przyda dla «Art Enfantin»?" (22.02.1979).

H. Semenowicz zajęła się na emeryturze tłumaczeniem wybranych prac Celestyna Freineta, które zostały wydane w publikacji $O$ szkołe Ludowq. Pisma wybrane, Ossolineum, Wrocław 1976; Niezmienne prawdy pedagogiczne, wyd. Polskie Stowarzyszenie Animatorów Pedagogiki C. Freineta, Otwock-Warszawa 1993; Gawędy Mateusza, wyd. Polskie Stowarzyszenie Animatorów Pedagogiki C. Freineta, Otwock-Warszawa 1993. H. Semenowicz opracowała także międzynarodową bibliografię pism Celestyna i Elizy Freinet, ich tłumaczeń oraz publikacji o Freinecie. Bibliografia ta została wydana przez Instytut Badań Pedagogicznych w Paryżu w 1986 r. Dziennik z 1979 r. zawiera wpis, w którym autorka wspomina o planach uporządkowania materiałów freinetowskich:

Po południu zadzwonił Aleksander. Chciałby on wstawić do planu pracy „uporządkowanie zebranych materiałów freinetowskich”. Będzie to bardzo trudne zadanie, bo w ciągu 20 lat zebrało się ponad 20 roczników czasopism, takich jak: Educateur, Arts Eufantins, około tysiąca broszur BT, BTJ i BT2, nie liczę już materiałów z kongresów, Biblioteki Nauczyciela BEM i różnych książek Elizy i Celestyna niefigurujących w przetłumaczonych pismach wybranych. Należałoby zatrudnić jakąś osobę znajacą dobrze j. francuski, co najmniej na 3 godziny dziennie, do składania tego wszystkiego, a ja mogłabym jedynie pełnić rolę konsultanta (04.12.1979).

Plany publikacyjne H. Semenowicz wykraczały poza tematykę zawodową. Zamierzała

napisać dwie książeczki dla dzieci - jedną o zwierzętach ${ }^{1}$, a drugą o dzieciach z różnych stron świata (23.02.1979). Chciałabym też przygotować mały tomik poezji dzieci dla „Biblioteki Poetów”, wydawnictwa Ludowej Spółdzielni Wydawniczej. Pomysł ten związany jest z Międzynarodowym Rokiem Dziecka (03.03.1979).

Diarystka myślała także, aby wydać wspomnienia zawodowe, gdyż „Wydawało mi się, że powinnam się podzielić swymi doświadczeniami z młodymi nauczycielami" (19.03.1979).

Niestety nie udało jej się napisać ani książek dla dzieci, ani wspomnień zawodowych.

\footnotetext{
1 „Teraz nie mam już żadnych wyrzutów, żeby się zabrać do pisania zaplanowanych pozycji do druku. Zacznę od opowiadań o zwierzętach dla dzieci i to już od poniedziałku. Oczywiście będzie to na razie pisanie «na próbę», bo jeszcze nie wiem, czy mi się uda utrafić w styl dostatecznie piękny językowo, a jednocześnie trafiający do dzieci" (03.03.1979).
} 
Zapisy w dziennikach pokazywały specyfikę pracy diarystki. Cechowała ją duża koncentracja na aktualnie wykonywanym zadaniu - w jego kontekście wszystkie inne sprawy traciły znaczenie:

(...) zasiadłam do zaniedbywanej broszury o Korczaku. Tak się nad tą pracą skoncentrowałam, że nawet nie wiem jak mi czas minął. (...) Zdaję sobie sprawę z tego, że zaniedbałam mnóstwo rzeczy - korespondencja, lektura, przyjemności kulturalne, wszystko leży odłogiem - a tu wcale nie widać końca tej pracy i chyba do połowy sierpnia się to przeciągnie (podsumowanie lipca, 1979).

Działo się tak, ponieważ autorka dzienników „Lubi[ła] skończyć jakąś pracę tak, aby być z niej zadowoloną" (11.09.1992). Dla H. Semenowicz istotna była rzetelność i profesjonalizm w pracy zawodowej. Denerwowała się i irytowała, gdy inni wykonywali niestarannie powierzone im zadania. 0 swoim niezadowoleniu $\mathrm{w}$ konstruktywny sposób informowała zainteresowane osoby, o czym świadczy wpis w dzienniku z 1992 r.:

Wczoraj otrzymałam zaproszenie na konferencję międzynarodową w Uniwersytecie Łódzkim na temat „Szkoły Alternatywnej”. Do zaproszenia dołączony był folder ośrodka wypoczynkowego w Dobieszkowie, należącego do Uniwersytetu, a w nim znajdowały się teksty tłumaczone na języki angielski, niemiecki i francuski. Tekst francuski zawiera ogromną ilość błędów językowych, gramatycznych i stylistycznych, co mnie kompletnie zbulwersowało. Nie mogę pojąć takiego braku poczucia odpowiedzialności. Przecież wysyłając taki najeżony błędami tekst musi on, u zaproszonych cudzoziemców, wywoływać brak zaufania do organizatorów i ośmieszyć nas. Dzisiaj napisałam list z podziękowaniem za zaproszenie, z którego nie skorzystam, ale też jasno i otwarcie przedstawiłam sprawę tego, pełnego błędów folderu (12.03.1992).

Zaangażowanie H. Semenowicz na emeryturze w pracę pisarską było formą kontynuacji aktywności zawodowej, na którą nie miała czasu w okresie przedemerytalnym. Pisząc książki i artykuły, mogła popularyzować pedagogikę C. Freineta w Polsce, a także prezentować własne refleksje, doświadczenia oraz idee pracy pedagogicznej z zastosowaniem technik francuskiego pedagoga. Świadczyło to o korzystaniu przez autorkę dzienników z zasobów wiedzy i doświadczenia zawodowego przez jak najdłuższy okres życia (Konieczna-Woźniak 2010: 227). Tłumaczenie artykułów i publikacji z języka francuskiego było dla diarystki także dodatkowym źródłem dochodu. „Z Instytutu Badań Pedagogicznych otrzymałam dzisiaj propozycję tłumaczenia referatu pana Beaudot z języka francuskiego. Przyjęłam chętnie tę pracę, bo pozwoli mi to zarobić parę groszy dodatkowych (19.09.1979)".

W 1988 r., podczas uroczystego seminarium w Warszawie, Halina Semenowicz przekazała przewodnictwo Komisji Koordynacyjnej Animatorów Pedagogiki Freineta Zofii Napiórkowskiej. Od tej pory była konsultantem i honorowym człon- 
kiem Polskiego Stowarzyszenia Animatorów Pedagogiki C. Freineta (Kowolik 2001: 264). Członkowie Stowarzyszenia zwracali się do pani Haliny jako eksperta o korektę, uwagi merytoryczne czy recenzję pisanych publikacji z zakresu pedagogiki Freineta:

Przeczytałam dziś książkę napisaną przez Krystynę Kowalską i tak jak jej obiecałam napisałam recenzję. Wyobraźnia plastyczna dziecka jest bardzo interesującą pracą i bardzo przydatną, nie tylko dla nauczycieli wychowania plastycznego, ale również dla animatorów plastycznych kół zainteresowań w różnych instytucjach kulturalnych i dla rodziców. Krystyna, która jest od wielu lat członkiem naszego zespołu freinetowskiego, zebrała w tej książce swoje doświadczenia i spostrzeżenia z siędemnastoletniej działalności w szkółce plastycznej, przez którą przeszło ponad 800 dzieci w wieku od 4 do 14 lat (24.05.1982).

Zabrałam się do przygotowania uwag do pracy Zosi Napiórkowskiej, nad bardzo potrzebną książką dla nauczycieli, nie tylko dla freinetowców, o samorządności, organizacji życia w klasie. Napisałam jej swoje uwagi w liście, a potem jeszcze rozmawiałyśmy o tym telefonicznie (15.01.2001).

Z zainteresowaniem i uwagą śledziła pracę lokalnych grup freinetowskich. Z zaangażowaniem uczestniczyła i pomagała koleżankom z ruchu freinetowskiego w organizacji kongresów, seminariów i warsztatów w kraju i za granicą: „Na poczcie znalazłam list okrężny Zespołu Animatorów Pedagogiki Freineta, bardzo ładnie zredagowany przez Zosię Napiórkowską i zaproszenie na seminarium 31 III i 1 IV. Mnie dotyczy pierwsza z tych dat, bo zebranie odbędzie się u mnie w Otwocku (06.03.1989)", a także sama poszukiwała nowych rozwiązań dydaktycznych, inspirowała się działaniami zagranicznych przyjaciół, należących do ruchu freinetowskiego:

Dzisiaj otrzymałam list od Anne, w którym przysłała mi obiecane druki informacyjne o fundacji francuskiej. Po przeczytaniu tych materiałów zorientowałam się, że nasze Towarzystwo Animatorów Pedagogiki Freineta będzie mogło skorzystać z pomocy tej fundacji po spełnieniu wymaganych warunków. Jutro rano napiszę list do Anne, żeby jej podziękować, a drugi list do Zosi Napiórkowskiej, żeby do mnie jak najprędzej przyjechała, aby omówić tę sprawę (05.02.1992).

Pani Halina starała się pozyskiwać nowych członków stowarzyszenia freinetowców, zwłaszcza znających język francuski:

Co za niespodzianka. Zatelefonowała dziś do mnie Hanka Szuniewicz, która jak się okazuje już jesienią wróciła do Polski i jest obecnie wizytatorem - metodykiem szkół specjalnych w kuratorium warszawskim. Muszę ją pozyskać dla naszego zespołu freinetowskiego, bo to bardzo wartościowy człowiek i poza tym zna dobrze j. francuski (29.01.1979). 
W dziennikach czytamy o spotkaniach pani Haliny z koleżankami ze Stowarzyszenia Animatorów Pedagogiki C. Freineta. Odwiedziny współpracowniczek „bliskich sercem, bo łączy nas wiele wspomnień i przeżyć" (31.03.1989) były serdecznymi, orzeźwiającymi i owocnymi spotkaniami-zebraniami, podczas których działaczki „opowiedziały mi o tym, co zrobiły na kursie w Sulejówku i podzieliły się swoimi pomysłami organizacyjnymi” (22.08.1979), omawiały „Szczegółowo «sesję freinetowską», która ma się odbyć w ich szkole w najbliższy piątek" (15.06.1982) $\mathrm{i}$ „przyszłe seminarium z udziałem eksperta postępu pedagogicznego, a także sprawy międzynarodowe” (02.02.1989), „plan pracy naszego zespołu, chcemy utworzyć sekcję freinetowską przy Związku Esperantów” (31.03.1989), dyskutowały „nad sprawami dotyczącymi planów naszego Stowarzyszenia. Powiększyło się o nowy zespół z Przemyśla” (10.10.1999), czy „spędzały czas na wspomnieniach dawnych lat" (28.06.2001). H. Semenowicz cieszyła się z podejmowanych przez koleżanki działań, wspierała je i pomagała w miarę swoich możliwości:

Freinetowców. Mam napisać odpowiedni list do Jean Le Gal'a, podając mu nazwiska i adresy, żeby każda Na kongres pojadą Bogusia, Wanda i Władzia na zaproszenie ICEM, oraz Zosia na zaproszenie Esperanto - otrzymała je [zaproszenie] indywidualnie i mogła wystąpić o paszport (31.03.1989).

Aktywnością quasi-zawodową, którą autorka dzienników wykonywała z przyjemnością i satysfakcją, było dzielenie się wiedzą i doświadczeniem zawodowym z nauczycielami i entuzjastami pedagogiki Freineta. W dziennikach wielokrotnie odnajdujemy adnotacje o wygłaszanych przez diarystkę referatach, wykładach podczas seminariów czy spotkaniach ze studentami, na które była zapraszana:

Byłam w studium pomaturalnych wychowania przedszkolnego na spotkaniu z młodzieżą. Opowiedziałam o miejscu, jakie zajmuje dziecko w koncepcji pedagogicznej Freineta i punktach wspólnych $\mathrm{w}$ tej dziedzinie z Korczakiem. Odpowiedziałam również na ich pytania, których było dość dużo i zupełnie inteligentne. Już wcześniej miałam dla nich referat na temat Freineta i jego techniki (07.11.1979).

Pani Halina udzielała konsultacji i pomagała w pisaniu prac dyplomowych. Przychodzącym do niej studentom autorka dzienników „usiłowała wytłumaczyć na czym polega organizacja środowiska wychowawczego $w$ duchu Freineta (07.01.1979), pomogła uporządkować materiał i ustalić zasady analizy rysunków dzieci (07.04.1979), czy zaopatr[ywała] w dodatkowe materiały" (24.01.1989).

Praca naukowa/zawodowa oraz aktywność twórcza Haliny Semenowicz wzbudzały zainteresowanie mediów. „Zwłaszcza książeczka „Chleb i róże” zainteresowała Radio Sygnały Dnia” (19.01.1979). Diarystka była zapraszana na nagrania audycji radiowych oraz programów telewizyjnych, gdzie opowiadała/wyjaśniała słuchaczom tematy związane z pedagogiką C. Freineta: 
Byłam w telewizji na spotkaniu z zespołem redaktorów audycji dla dzieci i nastolatków. Zaproszono mnie z prelekcją o swobodnej twórczości dziecka w kontekście pedagogiki C. Freineta (09.04.1979).

Zatelefonowała dziś do mnie redakcja pedagogiczna Polskiego Radia. Chcą ze mną zrobić wywiad na temat literackiej twórczości dziecka. Umówiłam się na poniedziałek godzina $11 \mathrm{u}$ mnie w domu (05.12.1979).

Jak sama pisała, „myśl udziału w takiej audycji sprawiła mi przyjemność" (19.01.1979). Pani Halina rozważała możliwość nawiązania współpracy z radiem: „Myślę, że zacznę znowu współpracę z Radiem. Zarysowuje się następna audycja o twórczych zabawach dziecka. Muszę na ten temat coś przygotować" (10.12.1979).

Z zapisów w dziennikach możemy dowiedzieć się, jak wyglądały/przebiegały jej przygotowania do pisania książek i artykułów: obmyślanie koncepcji tekstu, zbieranie informacji i materiałów:

Zasiadłam do zaniedbywanej broszury o Korczaku. (...) Musiałam przeczytać na nowo wszystkie dostępne prace Korczaka i o Korczaku, zrobić wybór i wypisać teksty i potem ten ogromny materiał uporządkować w jakąś całość (podsumowanie lipca, 1979).

Na podstawie wpisów możemy zaobserwować, że z biegiem lat pani Halina ograniczała wyjazdy na kongresy i seminaria organizowane za granicą i w innych miastach w kraju z powodu słabnącej aktywności fizycznej i pogarszającego się zdrowia. Także czynność pisania, z racji wieku, sprawiała jej coraz więcej kłopotów: szybko się męczyła, nie mogła zmotywować się do pisania, miała problemy z koncentracją, dlatego coraz częściej narzekała na złe samopoczucie i zaniedbania w pracy pisarskiej. „Pogoda nie sprzyja pracy twórczej. Nawet codzienny zapis w tym dzienniku sprawia mi wiele trudności” (15.02.1992). „Czuję się bardzo zmęczona, co wyraźnie odbija się na mojej wydolności” (23.01.2001).

Wykonywanie wbrew ograniczeniom pracy zgodnej z potrzebami, aspiracjami i umiejętnościami dla autorki dzienników stanowiło wyzwanie i zarazem nagrodę, dawało wiele radości, satysfakcji, prawdziwą realizację oraz spełnienie siebie. Nie dziwi więc, że pomimo przejścia na emeryturę pani Halina starała się kontynuować aktywność zawodową, wraz z upływem czasu w coraz węższym wymiarze.

\section{Wymiar edukacyjny aktywności zawodowej w świetle dzienników Haliny Semenowicz}

Praca od zawsze towarzyszyła człowiekowi jako jedna z zasadniczych form jego aktywności. Konieczność ograniczenia lub całkowitego jej zaprzestania prowadzi z kolei do znacznych zmian odczuwanych zarówno bezpośrednio (w związku 
z utratą dochodów), jak i pośrednio (w wyniku reorientacji relacji społecznych osoby biernej zawodowo). Dezaktywacja zawodowa pociąga za sobą zmiany w składowych kształtujących jakość życia i proces pomyślnego starzenia się człowieka, a tym samym zmusza go do podjęcia aktywności ukierunkowanych na przystosowanie się do nowej sytuacji - bycia na emeryturze. W tym kontekście aktywność zawodowa zawsze w rozmaitych okresach życia człowieka była i jest związana z edukacją.

W obliczu ograniczeń i strat towarzyszących starzeniu się ważnym wydaje się być poczucie ciągłości życia aktualnego względem dawnego. Przekonanie to wyraża Robert Atchley (1989) w swej koncepcji ciągłości, w myśl której zachowanie ciągłości wewnętrznej i zewnętrznej w stosunku do wcześniejszego życia stanowi warunek adaptacji do starości. Haliną Semenowicz, która kontynuowała aktywność zawodową po przejściu na emeryturę, kierowała potrzeba utrzymania dotychczasowego trybu codziennego życia, co jest charakterystyczne dla osób, od których praca zarobkowa wymagała dużego zaangażowania, w tym emocjonalnego, oraz szybkiego tempa działania (Bałandynowicz-Panfil 2010: 117). Brak takiej struktury po przejściu w stan bierności był odczuwalny przez H. Semenowicz, o czym świadczą rozpisywane w dziennikach harmonogramy pracy twórczej. Aktywność quasi-zawodowa pozwalała pani Halinie na utrzymywanie poziomu i jakości kontaktów społecznych, które były dla niej typowe we wcześniejszym, aktywnym zawodowo okresie. Udział w życiu zespołu freinetowskiego, z którym współpracowała, pomagał jej w budowaniu obrazu własnej osoby - aktywnej, pomimo ograniczonych możliwości fizycznych, świadczył o identyfikowaniu się z wartościami tej społeczności. W kontaktach ze studentami i młodymi nauczycielami, u których rozbudzała ciekawość alternatywnymi metodami dydaktycznymi, uczyła się bądź doskonaliła swoją umiejętność szanowania cudzej odmienności i autonomii przekonań, cierpliwości, wyrozumiałości, a także respektowania granic, jakie wyznacza drugi człowiek. Niewątpliwie podtrzymywanie aktywności zawodowej wiązało się z potrzebą czucia się przez panią Halinę potrzebnym i wartościowym członkiem społeczeństwa. Świadczą o tym wpisy autorki dzienników, która tłumacząc teksty dla koleżanek z ruchu freinetowskiego: „Bardzo się cieszę, że chociaż w ten sposób mogę czasem komuś pomóc, bo miło jest się czuć przydatną” (16.01.1979). „Pisanie listów dla przyjaciół $\mathrm{w}$ językach obcych jest jedną z moich funkcji społecznych, które bardzo lubię" (26.04.1982).

Halina Semenowicz, kontynuując aktywność zawodową po przejściu na emeryturę, doświadczała uczenia się przybierającego postać autoedukacji prowadzącej do zmieniania siebie, wymagającej zaangażowania emocjonalnego, ale także uczenia się polegającego na przyswajaniu określonej wiedzy sensu stricto. Pani Halina, pomimo rozległej wiedzy pedagogicznej oraz doświadczenia zawodowego, nieustannie dążyła do poszerzania i aktualizowania swoich kwalifikacji. W tym celu uczestniczyła w warsztatach i szkoleniach przygotowywanych przez koleżanki z ruchu freinetowskiego: „Seminarium było bardzo interesujące. Krystyna zrobiła 
dobrą robotę i dużo nas nauczyła z zakresu wychowania plastycznego" (21.03.1979).

Tworząc materiały metodyczne i broszury informacyjne „Wcale nie żałuję, że podjęłam się tej roboty, bo w ten sposób sama również pogłębiłam swą wiedzę o Korczaku" (27.07.1979). Ceniła uwagi francuskich przyjaciół, którzy sprawdzali pod kątem poprawności językowej i gramatycznej pisane przez nią artykuły do zagranicznych czasopism pedagogicznych:

Maria twierdzi, że nie robię prawie wcale błędów. Pokazała mi kilka usterek stylu (zgodność czasów, źle użyte que i qui - pierwsze używa się zamiast przedmiotu, drugie zamiast podmiotu: le cheval qui avait faim, mange l'herbe que je lui donnai) (26.05.1979).

Pod wieczór przyjechali kuzynowie Noela: Sarge i Maria Harzen, zrobili na mnie niezwykle sympatyczne wrażenie, ponieważ oboje, a zwłaszcza Sarge, są wielkimi znawcami języka francuskiego (i innych języków też). Poprosiłam, żeby przeczytali to, co dotąd napisałam i powiedzieli mi, czy warto dalej pisać po francusku. Ukazali mi kilka błędów, które się powtarzają (preposition i zgodność czasów) i bardzo zachęcali do dalszej pracy (04.06.1979).

Postęp nauki i techniki stawia każdego pracownika przed koniecznością uzupełnienia i/lub przeorganizowania własnego układu wiadomości w nowe struktury, które uwzględniłyby zmiany, jakie zaszły w organizacji procesu lub w koncepcjach pracy, w tej fazie edukacja w postaci doskonalenia zawodowego pełni funkcję renowacyjną i wyrównawczą (Kargul 2001: 133). W procesie doskonalenia zawodowego chodzi także o doskonalenie sfery emocjonalnej człowieka, jego postaw i kształtowanie takich sposobów myślenia i zachowania charakteryzujących jego aktywną postawę (tamże: 135). Aktualizowanie przez panią Halinę wiedzy zawodowej dawało jej poczucie kompetencji, którą wykorzystywała podczas udzielania konsultacji, a także dowodziło chęci uwolnienia się od schematycznego myślenia i postępowania, charakterystycznych dla osób $\mathrm{z}$ wieloletnim doświadczeniem zawodowym.

Za Hanną Solarczyk-Szwec można stwierdzić, że o efektach uczenia się decyduje przede wszystkim zdolność do refleksji nad tym procesem, która skutkuje krytycznym stosunkiem do edukacji, siebie i innych, co stanowić może drogę do emancypacji człowieka (Solarczyk-Szwec 2014: 96). Czytając dzienniki H. Semenowicz, odnajdujemy zapisy świadczące o podwyższonej świadomości własnych myśli, uczuć i wrażeń przez ich autorkę, która umożliwiała jej samoobserwację i rozważenie słuszności i skuteczności wykonywanej pracy. Pani Halina niejednokrotnie na kartach dziennika zastanawiała się nad stosowanymi przez siebie metodami dydaktycznymi. Lekcja języka angielskiego, którego uczyła koleżankę, skłoniła ją do refleksji na temat sposobów tłumaczenia obcojęzycznych tekstów: 
Naturalnie główne w tym wszystkim jest zrozumienie intuicyjne, a potem dopiero szuka się słów w słowniku, żeby uszczegółowić ogólny sens pojęty na początku. Jeszcze trudniej jest tłumaczyć z polskiego na inny język, np. na francuski, ale i tu chyba przydatna jest ta sama metoda: od ogólnie ujętej myśli do szczegółowych wyrażeń i słów - przynajmniej ja tak właśnie postępuję (21.01.1979).

Refleksja H. Semenowicz nad fenomenem technik Freineta, które cieszyły się dużym zainteresowaniem wśród pedagogów na całym świecie, wyróżniała się dociekliwością oraz rozpatrywaniem tych spraw w świetle ich uwarunkowań i konsekwencji:

Udział w obradach ICEM i rozmowy z wielu kolegami upewniły mnie w przekonaniu, że nasz ruch freinetowski nadal się rozwija i rozszerza swe kręgi o coraz to nowe szeregi młodych, bardzo zapalonych nauczycieli. Dostrzega się też wyraźnie chęć pogłębienia teoretycznego koncepcji pedagogicznej Freineta i dopasowanie jej do aktualnych potrzeb szkolnictwa francuskiego. Nadal nie potrafię odpowiedzieć sobie na pytanie, które mnie od lat fascynuje: co sprawia, że pedagogika Freineta i zainicjowany przez niego ruch pedagogiczny, wykazują stale tendencje rozwojowe i rozszerzają się w wielu krajach po śmierci twórcy École Moderne? Bo przecież większość, a właściwie wszystkie inne kierunki Nowego Wychowania, takie jak Decroly, Montessori, Dewey, czy Steiner legitymizują się zaledwie pewną ilością szkół eksperymentalnych prywatnych, dla ograniczonej liczby dzieci, raczej warstw uprzywilejowanych, zamożnych. Być może przyczyną szerokiego upowszechnienia pedagogiki Freineta jest to, że potrafił on uruchomić ruch oddolny nauczycieli i że jego techniki nauczania i wychowania ukierunkowane są na dzieci ludu, a jednocześnie, przez ich współdzielczy charakter, dają możliwość nowego życia w szkole? (18.10.1982).

Starzenie się, jak dostrzega Olga Czerniawska, nie jest złem, któremu trzeba się podporządkować, jest powołaniem, na które trzeba umieć odpowiedzieć (Czerniawska 2007: 236). W tym kontekście podejmowane przez Halinę Semenowicz aktywności w obszarze pracy sprzyjały pozytywnemu starzeniu się, będącemu umiejętnością wyboru celów życiowych i zadań adekwatnych do możliwości oraz ich systematyczne i konsekwentne realizowanie. Jak podkreśla Robert D. Hill, to człowiek wpływa na przebieg swojego procesu starzenia się niezależnie od deficytów pojawiających się z upływem lat życia. Teza ta jest istotna dla andragogiki czy gerontologii, ponieważ pokazuje możliwość celowego i świadomego oddziaływania człowieka starszego na własny rozwój poprzez wykorzystanie osobistych zasobów (Konieczna-Woźniak 2013: 452). Autorka dzienników, pozostając aktywną i autonomiczną osobą, „zabezpieczyła” się na starość w tzw. aktywny styl życia, który pełnił rolę czynnika odmładzającego. Jak zauważa Jerzy Halicki (2010: 235) „Aktywny lub bierny styl życia w starości jest zazwyczaj przedłużeniem stylu dotychczas prowadzonego". 
Aktywność zawodowa była wartością w życiu Haliny Semenowicz. W dziennikach odnotowywała każdą podejmowaną pracę. W kalendarzach od 1979 (pierwszy w całości zapisany dziennik) do 2001 r. odnajdujemy wpisy świadczące o zaangażowaniu w pracę pisarską i nieustannym zainteresowaniu autorki działaniami ruchu freinetowskiego. Świadczy o tym także częstotliwość używanych przez autorkę dzienników określeń w odniesieniu do obszaru pracy. Najczęściej powtarzającym się słowem była praca, która w dzienniku z 1979 r. pojawiła się 121 razy, w 1982 r. - 57 razy, w 1989 r. - 111 razy, 1992 r. - 86 razy, w 1999 r. - 79 razy, a w 2001 r. - 46 razy. Zmniejszenie częstotliwości używania wyrazu praca w dzienniku z 1982 r. było spowodowane koncentracją uwagi diarystki na panującej ówcześnie w kraju sytuacji politycznej. Kolejnym, często wymienianym słowem było pracowałam. W dzienniku z 1979 r. zostało ono użyte 66 razy, w 1982 r. - 24 razy, w 1989 r. - 40 razy, 1992 r. - 31 razy, w 1999 r. - 27 razy, a w 2001 r. - 29 razy. Pani Halina często wymieniała słowa przetłumaczyłam i tłumaczyłam, które w dzienniku z 1979 r. pojawiają się 22 razy, w 1982 r. - 6 razy, w 1989 r. - 37 razy, 1992 r. - 29 razy, w 1999 r. - 4 razy, a w 2001 r. - 5 razy. Znaczne zmniejszenie częstotliwości używania tych słów w dzienniku z 1982 r. wynikało z obciążenia aktualnymi warunkami [politycznymi], w jakich żyjemy tutaj od prawie miesiąca (07.01.1982). W roku 1999 autorkę dziennika zajmowała choroba młodszej córki Danuty, dlatego nie podejmowała aktywności quasi-zawodowych. Z powodów zdrowotnych pani Halina większą część roku 2001 spędziła w pensjonacie „Złoty Wiek” w Ładach, gdzie „Zupełnie nie mam czasu ani na korespondencję, ani na pisanie wspomnień" (10.03.2001).

Pisanie dariusza, będącego formą (auto)biografii, otwiera przed człowiekiem jego wnętrze, jak zauważa Agnieszka Bron, „wykorzystując samoświadomość, uczymy się z naszych biografii przez podsumowanie, refleksję, samorefleksję, opowiadanie historii innym i samym sobie" (Bron 2006: 64-65). Przedstawione w tekście dzienniki ukazują indywidualną, niepowtarzalną historię życia Haliny Semenowicz, która próbuje odnaleźć się na nowym etapie swojego życia i w nowej roli, poprzez kontynuację pracy zawodowej. Prezentowany obszar życia, jakim była praca, zawiera wiedzę o autorce dzienników jako pracowniku i jej stosunku do pracy, ukazuje obraz osoby ambitnej, refleksyjnej oraz nieustępliwej w swych działaniach. Autorka dzienników z zaangażowaniem wykonywała swoją pracę, była silną i charyzmatyczną osobowością, która skupiła wokół siebie wielu ludzi zainteresowanych technikami pracy z dzieckiem francuskiego pedagoga. Zaangażowanie w działania SAPF dawało jej satysfakcję z możliwości dalszego uczestniczenia w jego tworzeniu, ale także wymagało od niej dyscypliny i wytrwałości, zwłaszcza podczas pisania artykułów czy referatów, co z czasem nastręczało wiele trudności (zmniejszona koncentracja, kłopoty w pisaniu spowodowane zmęczeniem czy chorobą). Poprzez podejmowanie działań quasi-zawodowych autorka dzienników nadawała sens swemu życiu, chciała uczynić je lepszym, godniejszym i bardziej 
wartościowym. Omawiany obszar stanowił ważną treść jej życia, którą starała się wypełnić życie teraźniejsze, czas spędzany na emeryturze. Praca dawała H. Semenowicz wiele radości i satysfakcji.

\section{Bibliografia}

Atchley R. (1989) A continuity theory of aging, „Gerontologist”, no 29, 183-190.

Bałandynowicz-Panfil K. (2010) Znaczenie aktywności zawodowej dla jakości życia osób starszych w: Jakość życia seniorów w XXI w. Ku aktywności, D. Kałuży, P. Szukalskiego (red.), Łódź, Wydawnictwo Biblioteka, s. 112-121.

Bron A. (2006) Rozumienie uczenia się w teoriach andragogicznych, „Teraźniejszość Człowiek - Edukacja”, nr 4, s. 7-23.

Czerniawska 0. (2007) Edukacja osób „trzeciego wieku” w: Wprowadzenie do andragogiki, T. Wujek (red.), Radom, Wydawnictwo Uniwerystetu w Białymstoku, s. 213-236.

Halicki J. (2010) Obrazy starości rysowane przeżyciami seniorów, Białystok, Wydawnictwo Uniwersytetu w Białymstoku.

Hill R. D. (2005) Pozytywne starzenie się. Młodzi duchem w jesieni życia, Warszawa, Wydawnictwo „Biznes”.

Kargul J. (2001) Obszary pozaformalnej i nieformalnej edukacji dorosłych. Przesłanki do budowy teorii edukacji całożyciowej, Wrocław, Wydawnictwo Naukowe Dolnośląskiej Szkoły Wyższej Edukacji TWP.

Konieczna-Woźniak R. (2013) Uczenie się pozytywnym wymiarem życia w fazie później dorosłości w: Całożyciowe uczenie się jako wyzwanie dla teorii i praktyki edukacyjnej, E. Solarczyk-Ambrozik (red.), Poznań, Wydawnictwo Naukowe UAM, s. 447-459.

Konieczna-Woźniak R. (2016) Starość czasem samorealizacji - subiektywne i obiektywne postrzeganie zjawiska w: Obiektywny i subiektywny wymiar starości, E. Dubas, M. Muszyński (red.), t. 1, Łódź, Wydawnictwo Uniwersytetu Łódzkiego, s. 221-232.

Kościuszko M. (2014) Dr Halina Semenwoicz - pedagog poszukujący. Twórczyni ruchu freinetowskiego w Polsce w: Inspiracje pedagogia freinetowską. Studia, źródła, wspomnienia dedykowane Halinie Semenowicz, A. Semenowicz, H. Solarczyk, A. Szwech (red.), Toruń, Wydawnictwo Naukowe UMK, s. 147-159.

Kowolik P. (2001) Halina Semenowicz - inicjator i animator ruchu „Pedagogiki Celestyna Freineta” w Polsce, „Nauczyciel i Szkoła”, nr 3-4, s. 262-265. 
Kvale S. (2010) Prowadzenie wywiadów, Warszawa, Wydawnictwo Naukowe PWN.

Rubacha K. (2008) Metodologia badań nad edukacja, Warszawa, Wydawnictwa Akademickie i Profesjonalne.

Semenowicz A., Solarczyk H., Szwech A. (red.) (2014) Inspiracje pedagogia freinetowską. Studia, źródła, wspomnienia dedykowane Halinie Semenowicz, t. 1, Toruń, Wydawnictwo Naukowe UMK.

Słowińska S. (2014) Koncepcja małych światów przeżywanych - fenomenologiczne inspiracje dla andragogiki, „Edukacja Dorosłych”, nr 2, s. 91-104.

Solarczyk-Szwec H. (2014) Uczenie się przez całe życie jako metakompetencja w: Ewaluacja poprawy jakości kształcenia, J. Grzesiak (red.), Kalisz-Konin, s. 93-101.

Solarczyk-Szwec H., Szwech A. (red.) (2016) Inspiracje pedagogiq freinetowską. Dzienniki Haliny Semenowicz - matki i obywatelki, t. 2, Toruń, Wydawnictwo Naukowe UMK.

Szwech A. (2012) Obszary uczenia się przez całe życie w dziennikach Haliny Semenowicz, „Rocznik Andragogiczny”, vol. 19, s. 264-271.

Szwech A. (2016) Subiektywny wymiar starości w świetle dzienników Haliny Semenowicz w: Obiektywny i subiektywny wymiar starości, E. Dubas, M. Muszyński (red.), t. 1, Łódź, Wydawnictwo Uniwersytetu Łódzkiego, s. 185-192. 